\title{
AMNION LIOFILISASI EFEKTIF MENYEMBUHKAN REAKSI KULIT AKIBAT RADIOTERAPI PADA PASIEN KANKER
}

\author{
Arifianto $^{1}$, Menkher Manjas ${ }^{1}$, Benni Raymond ${ }^{1}$, Edison $^{2}$
}

\begin{abstract}
Abstrak
Reaksi kulit jaringan sekitar sering terjadi akibat efek samping radioterapi pada tumor. Membran amnion dapat dipakai sebagai pengobatan lokal karena kemampuannya mempercepat penyembuhan luka. Penelitian ini bertujuan untuk membandingkan efektifitas amnion liofilisasi dengan salep gentamisin terhadap penyembuhan reaksi kulit akibat radioterapi. Jenis penelitian ini adalah experimental, pada 16 pasien kanker yang mengalami reaksi kulit akibat radioterapi di unit Radioterapi RSUP Dr. M. Djamil Padang. Pasien dikelompokan menjadi 2 kelompok yaitu kelompok diberi terapi amnion liofilisasi dan kelompok yang diberi salep gentamisin. Alat ukur yang digunakan adalah tabel skala RISRAS yang dikembangkan oleh Noble-Adams. Pengukuran dilakukan tiga kali yaitu sebelum perlakuan, setelah 1 minggu dan setelah 2 minggu perlakuan. Analisis statistik menggunakan T-Test dengan nilai $p<0,05$. Hasil penelitian ini didapatkan perbedaan yang bermakna penurunan Skala RISRAS pada kelompok yang diberi amnion dibandingkan dengan yang diberi salep gentamisin pada penilaian setelah 1 minggu perlakuan $(p=0,007)$. Penelitian ini dapat disimpulkan bahwa amnion liofilisasi memberikan penyembuhan luka yang lebih cepat dibandingkan salep gentamisin.
\end{abstract}

Kata kunci: reaksi kulit, Skala RISRAS, amnion liofilisasi, salep gentamisin

\begin{abstract}
Skin reactions of surrounding tissue is often a side effect of cancer radiotherapy. Amniotic membrane can be used as a local treatment because of its ability to accelerate wound healing. This study aimed to compare the efficacy of amniotic lyophilization with gentamicin ointment to cure skin reactions due to radiotherapy. This type of research is experimental, on 16 cancer patients who experience skin reactions due to radiotherapy at the department of Radiotherapy Dr. M. Djamil Padang. Patients were classified into 2 groups: group with treatment by lyophilization amnion and group who were given gentamicin ointment. Measuring instrument used is a table RISRAS scale developed by Noble-Adams. Measurements were performed three times; prior to treatment, after 1 week and after 2 weeks of treatment. Statistical analysis using the T-test with $p<0.05$. The results of this study found significant differences Scale RISRAS decline in the group given by amnion compared with gentamicin ointment on assessment after 1 week of treatment $(p=0.007)$. It was concluded that lyophilized amniotic provide wound healing faster than gentamicin ointment.
\end{abstract}

Keywords: skin reaction, RISRAS, lyophilized amniotic, gentamicin ointment

Afiliasi Penulis: 1. Bagian IImu Bedah Fakultas Kedokteran Universitas Andalas/RSUP DR. M. Djamil Padang, 2. Bagian IImu Kesehatan Masyarakat Fakultas Kedokteran Andalas Padang. Korespondensi: Arifianto. Email: arifiantomd@gmail.com. 


\section{PENDAHULUAN}

Radioterapi merupakan komponen penting dalam penanganan kanker disamping tindakan pembedahan dan kemoterapi. ${ }^{1,2}$ Radioterapi merusak DNA pada sel kanker sehingga menghambat kemampuan untuk membelah dan berproliferasi. Selain menyebabkan kerusakan pada sel kanker, radioterapi juga menyebabkan kerusakan pada sel normal disekitarnya. ${ }^{1}$ Salah satu efek yang paling sering terjadi pada pasien yang dilakukan radioterapi adalah reaksi kulit akut. ${ }^{1-4}$

Paparan radiasi dapat menginduksi respon inflamasi jaringan dengan mensekresikan histamin dan serotonin. Efek lain yang ditimbulkan yaitu dilatasi kapiler dan cedera pada ekstrakapiler. ${ }^{4-6}$ Kehilangan sel basal terjadi ketika dosis radiasi berkisar 20-25 Gy dan deplesi maksimum sel basal pada dosis $50 \mathrm{~Gy} .{ }^{4}$ Reaksi kulit dapat terjadi setelah 2-3 minggu pengobatan dan bisa menetap sampai 4 minggu setelah pengobatan selesai. ${ }^{3,4}$ Kelenjer keringat dan kelenjer sebasea akan mengalami kerusakan permanen setelah dosis 30 Gy (15 fraksi) selama periode 3 minggu. Hal ini akan menyebabkan penurunan lubrikasi kulit sehingga menyebabkan kekeringan dan pruritus. ${ }^{6}$

Reaksi kulit yang terjadi mempunyai derajat yang bervariasi mulai dari eritema yang ringan sampai timbulnya deskuamasi basah (moist desquamation) dan ulserasi kulit. ${ }^{2,5}$ Ketidaknyamanan akibat radioterapi itu dapat mempengaruhi kualitas hidup pasien kanker. ${ }^{2,3,5} \mathrm{Jika}$ radioterapi dihentikan sementara waktu tentu saja hal ini akan berpengaruh terhadap hasil pengobatan pada pasien. ${ }^{3,5}$
Tujuan penanganan reaksi kulit akibat radioterapi tersebut adalah untuk mempertahankan keutuhan dan hidrasi kulit, memberikan kenyamanan, mengurangi nyeri, mencegah trauma, mencegah infeksi dan menciptakan lingkungan penyembuhan luka yang moist (lembab). ${ }^{6}$ Banyak cara pengobatan yang dilakukan untuk menangani reaksi kulit akibat radioterapi diantaranya adalah menggunakan obat oral, intravena, dan berbagai obat topikal. ${ }^{2}$ Namun saat ini belum terdapat obat yang bisa menjadi standar dalam penanganan reaksi kulit. ${ }^{7,8}$ Cara mempertahankan hidrasi kulit dengan mengunakan berbagai moisturizer, krim barrier, aloe vera, lanolin, dan krim steroids. ${ }^{9,10}$ Peter menemukan bahwa sekitar $77,5 \%$ pasien sembuh dengan pemberian salep dan kompres basah. ${ }^{11}$

Penggunaan dressing dalam penanganan reaksi kulit berdasarkan pemahaman bahwa lingkungan penyembuhan luka yang lembab akan mempercepat laju reepitelisasi. Luka yang dipelihara kelembabannya akan mengalami penyembuhan $50 \%$ lebih cepat. $^{6}$ Penggunaan dressing untuk deskuamasi basah didasarkan pada premis akan kemampuannya untuk mencegah trauma, mempertahankan kelembaban, mempercepat reepitelisasi dan mencegah infeksi. ${ }^{5}$ Penelitian yang dilakukan Gajiwala bahwa menggunakan dressing amnion pada deskuamasi basah dan membran amnion dapat mempercepat epitelisasi. Amnion juga memberikan barrier yang efektif terhadap trauma dan panetrasi bakteri. ${ }^{5,12}$

Membran amnion telah lama dikenal sebagai dressing biologis pada luka. ${ }^{13,14}$ Membran amnion mempunyai kemampuan 
merangsang penyembuhan luka seperti meningkatkan pembentukan jaringan kolagen, mempercepat epitelisasi, dan pembentukan pembuluh darah baru. ${ }^{14,16}$ Membran amnion mengandung faktor angiogenetic dan mitogenic sehingga dapat mempercepat proses penyembuhan luka. ${ }^{16}$ Faktor angiogenetic berperan pada endotel kapiler dan menginduksi pembentukan pembuluh darah baru. ${ }^{13}$

Standar baku penanganan reaksi kulit di unit Radioterapi RSUP Dr. M. Djamil saat ini belum ada. Penanganan reaksi kulit untuk saat ini hanya diberikan salep antibiotik gentamisin. Gentamisin merupakan prototipe antibiotik golongan aminoglikosida. Aktifitas utama gentamisin tertuju pada basil gram negatif yang aerobik, sedangkan aktifitas terhadap bakteri yang anaerobik rendah. ${ }^{17}$

Penelitian ini bertujuan untuk membandingkan efektifitas amnion liofilisasi dengan salep gentamisin terhadap penyembuhan reaksi kulit akibat radioterapi.

\section{METODE}

Penelitian ini adalah studi experimental dengan metode penelitian prospektif. ${ }^{18,19}$ Penelitian dilakukan di unit Radioterapi RSUP Dr. M. Djamil Padang dari bulan Maret-Juni 2015 pada pasien yang menjalani radioterapi untuk kanker payudara, kanker kepala dan leher. Pasien mengalami reaksi kulit derajat 2 (deskuamasi kering) dan derajat 3 (deskuamasi basah), mendapatkan dosis radiasi 50-70Gy, dan usia 18-60 tahun. Penderita penyakit diabetes mellitus, malnutrisi, dan kontrol tidak teratur tidak diikutkan dalam penelitian. Pengukur reaksi kulit digunakan skala The Radiation-Induced
Skin Reaction Assesment Scale (RISRAS) yang dikembangkan Noble-Adams tahun 1999. Skala RISRAS terdiri dari komponen simptom pasien dengan nilai skor maksimal 16 dan komponen penilaian profesional dengan skor maksimal 10. Nilai Skala RISRAS adalah penjumlahan komponen pasien dan penilaian professional dengan nilai skor berada pada range 4-26.

Perhitungan skala RISRAS dilakukan pada awal minggu ke-4 siklus radioterapi, atau pada saat mulai terjadi deskuamasi basah. Kelompok pertama amnion liofilisasi, kelompok kedua diberikan salep gentamisin. Setelah mendapat perlakuan pasien dilakukan follow-up 2 kali dalam seminggu sampai selesai program radioterapi. Kemudian dilakukan penilaian reaksi kulit 1 kali setiap minggu. Penilaian simptom pasien dilakukan oleh peneliti sedangkan professional dilakukan secara single blind berdasarkan penilaian fotografi klinis serial menggunakan kamera digital Nikon $D$ 3100, AF-S NIKKON 18-55mm1: 3,5-5,6 G, dengan pengaturan cahaya otomatis. Jarak pengambilan $50 \mathrm{~cm}$ dari obyek, diambil dalam ruangan tertutup, penerangan cahaya 60 watt. Foto di sertakan dengan penggaris yang diperlukan untuk perhitungan luas reaksi kulit. Penilaian skala RISRAS dilakukan 3 kali: sebelum terapi, setelah 1 minggu dan setelah 2 minggu terapi.

\section{HASIL DAN PEMBAHASAN}

Karakteristik subyek diperlihatkan pada tabel 1, dimana tidak didapatkan perbedaan yang bermakna secara statistik umur, jenis kelamin, lokasi radiasi, indeks massa tubuh, riwayat merokok, jumlah fraksi dan mulai terapi pada kedua kelompok. 
Tabel 1. Karakteristik dan Skedul Radioterapi

\begin{tabular}{|c|c|c|c|}
\hline Variabel & $\begin{array}{c}\text { Amnion } \\
(n=8)\end{array}$ & $\begin{array}{l}\text { Salep Gentamisin } \\
(n=8)\end{array}$ & $\mathbf{p}$ \\
\hline Umur (mean \pm SD) & $48,63 \pm 6,67$ & $46,50 \pm 13,06$ & 0,688 \\
\hline \multicolumn{4}{|l|}{ Jenis Kelamin } \\
\hline Laki-laki & 6 & 4 & 0,304 \\
\hline Perempuan & 2 & 4 & \\
\hline \multicolumn{4}{|l|}{ Lokasi radiasi } \\
\hline Dada & 1 & 2 & 0,500 \\
\hline Kepala dan leher & 7 & 6 & \\
\hline Indeks massa tubuh (mean $\pm \mathrm{SD}$ ) & $22,25 \pm 3,29$ & $22,08 \pm 3,23$ & 0,918 \\
\hline \multicolumn{4}{|l|}{ Riwayat Merokok } \\
\hline Ada & 6 & 4 & 0,304 \\
\hline Tidak Ada & 2 & 4 & \\
\hline \multicolumn{4}{|l|}{ Jumlah Fraksi } \\
\hline $25 \times 2$ gy & 1 & 2 & 1,00 \\
\hline $33 \times 2$ gy & 3 & 4 & \\
\hline $35 \times 2$ gy & 4 & 2 & \\
\hline \multicolumn{4}{|l|}{ Mulai terapi } \\
\hline$\leq 20$ fraksi & 2 & 4 & 0,304 \\
\hline$>20$ fraksi & 6 & 4 & \\
\hline
\end{tabular}

Penilaian skala RISRAS dapat dilihat pada tabel 2, dimana secara statistik terdapat perbedaan yang bermakna antara nilai awal skala RISRAS kelompok amnion liofilisasi dengan kelompok salep gentamisin $(p=0,046)$. Penilaian skala RISRAS pada minggu pertama dan minggu kedua perlakuan tidak terdapat perbedaan yang bermakna antara kedua kelompok.

Penurunan Skala RISRAS pada kedua kelompok terdapat perbedaan yang bermakna setelah dilakukan terapi selama 1 minggu ( $p=0,007)$, sedangkan yang diberikan terapi selama 2 minggu tidak terdapat perbedaan $(p=0,316)$.

Tabel 2. Perbedaan Rerata Skala RISRAS

\begin{tabular}{cccc}
\hline Waktu Penelitian & Amnion Liofilisasi & Salep Gentamisin & P \\
\hline Sebelum Perlakuan & $13,38 \pm 1,06$ & $12,25 \pm 1,16$ & 0,063 \\
Simptom & $5,38 \pm 1,09$ & $4,75 \pm 0,93$ & 0,238 \\
Penilaian professional & $18,88 \pm 1,75$ & $17,00 \pm 1,67$ & 0,046 \\
Minggu 1 & $8,00 \pm 0,93$ & $9,75 \pm 1,28$ & 0,007 \\
Simptom & $3,50 \pm 1,13$ & $2,75 \pm 1,64$ & 0,307 \\
Penilaian professional & $11,50 \pm 1,51$ & $12,50 \pm 2,38$ & 0,332 \\
Minggu 2 & 0,332 & $6,63 \pm 1,85$ & 0,011 \\
Simptom & $1,00 \pm 1,87$ & $1,19 \pm 2,26$ & 0,859 \\
Penilaian professional & $5,50 \pm 2,79$ & $7,81 \pm 3,99$ & 0,201 \\
\hline
\end{tabular}

Tabel 3. Perbedaan Rerata Penurunan Skala RISRAS

\begin{tabular}{lccc}
\hline \multicolumn{1}{c}{ Waktu Penelitian } & Amnion liofilisasi & Salep Gentamisin & P \\
\hline Minggu 1 & $5,38 \pm 1,41$ & $2,75 \pm 0,71$ & 0,000 \\
Simptom & $1,88 \pm 1,19$ & $2,00 \pm 1,10$ & 0,830 \\
Penilaian professional & $7,38 \pm 2,16$ & $4,50 \pm 1,44$ & 0,007 \\
Minggu 2 & $8,88 \pm 1,36$ & $5,63 \pm 2,07$ & 0,002 \\
Simptom & $4,38 \pm 1,46$ & $3,69 \pm 1,87$ & 0,426 \\
Penilaian professional & $12,06 \pm 3,39$ & $10,44 \pm 2,82$ & 0,315 \\
\hline
\end{tabular}

Salep gentamisin menurunkan Skala RISRAS dengan rerata $4,50 \pm 1,44$ pada p-ISSN: 0126-2092; e-ISSN: 2442-5230 minggu pertama, sedangkan pada minggu kedua rerata penurunan Skala RISRAS 
adalah 10,44 $\pm 2,82$. Hasil penelitian ini ditemukan sebanyak $62,5 \%$ yang menggunakan salep gentamisin mengalami penyembuhan pada minggu kedua. Penelitian yang sama oleh Peter juga melaporkan bahwa 77,5\% sembuh dengan pemberian salep dan pemberian kompres basah. $^{11}$

Penelitian ini menggunakan salep gentamisin yang mengandung basis salep zat hidrokarbon yaitu paraffin. Basis hidrokarbon pada salep memiliki sifat moisturizer dan emollient yaitu mampu meningkatkan hidrasi dan mempertahankan kelembaban kulit. Efek moisturizer pada salep sangat bermanfaat pada kondisi kulit yang kering. Kerja utamanya adalah dengan memberikan lapisan lemak pada permukaan kulit sehingga mencegah evaporasi air dari permukaan kulit. ${ }^{11}$

Amnion liofilisasi menurunkan Skala RISRAS dengan rerata $7,38 \pm 2,16$ pada minggu pertama, sedangkan pada minggu kedua rerata penurunan Skala RISRAS adalah $12,06 \pm 3,39$. Penggunaan amnion liofilisasi 6 dari 8 pasien (75\%) mengalami penyembuhan dalam waktu 2 minggu. Gajiwala et al mendapatkan bahwa membran amnion berhasil dalam penanganan deskuamasi basah. Membran amnion memberikan suatu barrier yang efektif terhadap trauma dan panetrasi bakteri. Amnion juga membantu dalam menciptakan lingkungan fisiologis yang lembab dan mempercepat penyembuhan luka.

Membran amnion mempercepat epitelisasi dan mengurangi frekwensi pergantian dressing. ${ }^{5,} 12$ Amnion liofilisasi mudah digunakan dan menempel dengan baik pada lokasi pemberian. Hal ini menjadi penting pada area yang sulit seperti daerah inguinal, karena amnion dapat menempel dengan kuat pada permukaan yang irregular. ${ }^{12}$ Gajiwala et al melaporkan bahwa penyembuhan reaksi kulit menggunakan membran amnion adalah 7 hari. ${ }^{12}$

Penelitian ini didapatkan amnion liofilisasi menurunkan Skala RISRAS lebih cepat dibandingkan dengan salep gentamisin pada penilaian minggu pertama. Sebagaimana dijelaskan dalam literatur bahwa penyembuhan jaringan normal dihasilkan melalui rangsangan homeostatic atau feedback dengan terjadinya reepitelisasi dan differensiasi sel dari membran basal disertai migrasi sel epitel dari luar lapangan pengobatan. ${ }^{6}$ Reepitelisasi biasanya dimulai kira-kira pada hari ke-10. Lingkungan atau kondisi luka yang lembab menyebabkan terjadinya migrasi sel ke arah area reaksi kulit yang terjadi. $^{6}$ Radiasi berulang menyebabkan peningkatan ekspresi dari sitokin transforming growth factor- $\beta$ (TGF- $\beta$ ) dan tumor necrosis factor $\alpha$ (TNF- $\alpha)$, vascular endothelial Growth factor (VEGF), dan interleukin (IL). Hal ini menyebabkan terjadinya akumulasi matriks yang tak terkontrol, ekspresi keratin yang abnormal oleh keratinosit, disorganisasi deposisi kolagen, remodeling jaringan lunak yang tidak adekuat oleh fibroblast, irreguler angiogenesis, menyebabkan fibrosis dan keterlambatan penyembuhan luka. Penyembuhan reaksi kulit membutuhkan suatu pengaturan kompleks dari sitokin dan growth factor dan reseptornya yang terputus akibat cedera radiasi berulang. ${ }^{5}$

Membran basement pada amnion mengandung collagen tipe IV dan VII, laminin-1, laminin-5, fibronectin, allantoin, lisozym, transferrin, progesteron dan 
beberapa jenis faktor pertumbuhan. Disamping itu membran amnion mengandung sejumlah sitokin penting diantaranya platelet-activating factor (PAF), basic-fibroblast growth factor (b-FGF), hepatocyte growth factor (HGF), placental proliferin, TGF- $\beta$, dan epidermal growth factor (EGF). ${ }^{22}$ Membran amnion juga mengekspresikan sitokin pro-inflammatory (IL-1, IL-6, IL-8, dan TNF- $\alpha$ ) yang mengaktifkan respon pertahanan lokal bila terjadi invasi bakteri dan endotoksinnya. ${ }^{20}$

Membran amnion mempunyai kemampuan untuk mencegah evaporasi, menempel erat pada reseptor, menahan shearing force, mencegah infeksi, bisa menyesuaikan pada permukaan yang irreguler, dan kemampuan untuk mengurangi nyeri. ${ }^{13,15}$ Mengatasi nyeri adalah faktor yang penting dalam penanganan luka. Salah satu respon terhadap nyeri adalah vasokontriksi yang akan mempengaruhi proses penyembuhan luka ${ }^{21}$. Sebagian besar pasien pada penelitian yang menggunakan amnion merasakan berkurangnya rasa nyeri. Hal ini terjadi karena penurunan proses inflamasi dan status hidrasi yang lebih baik dari bed luka. Menjaga hidrasi kulit merupakan salah satu cara mengatasi nyeri pada kulit yang luka. ${ }^{21}$ Penjelasan lain adalah lapisan mukoid yang lembut dari membran amnion melindungi ujung syaraf yang terekspos dari iritasi eksterna dari udara luar. ${ }^{15}$ Penurunan rasa nyeri sehubungan dengan akseptabilitas pasien terhadap amnion. ${ }^{11}$

Penelitian ini didapatkan 7 orang (87,5\%) kelompok amnion mempunyai reaksi kulit derajat 3 (deskuamasi basah) sedangkan pada kelompok salep gentamisin reaksi kulit derajat 3 terdapat pada 2 orang
(25\%). Visvanath mendapatkan bahwa pasien yang mengalami reaksi kulit lebih dalam akan membutuhkan waktu penyembuhan yang lebih lama $(12,67 \pm 5,13$ hari), sedangkan pada lesi epidermis superfisial waktu penyembuhan lebih cepat yaitu 4,53 $\pm 2,07$ hari. $^{21}$

Setelah pemberian terapi selama 2 minggu 6 orang (75\%) kelompok amnion sudah kembali pada kulit normal, sedangkan pada kelompok salep gentamisin pada minggu kedua 5 orang $(62,5 \%)$ sudah kembali pada kulit normal. Walaupun diawal terapi terdapat perbedaan dalam derajat reaksi kulit pada kedua kelompok, tetapi setelah pemberian terapi selama 2 minggu sebagian besar pasien pada kedua kelompok sudah kembali ke kulit yang normal.

Percepatan regenerasi dan epitelisasi serta peningkatan granulasi dengan membran amnion disebabkan adanya faktor angiogenik dan faktor pertumbuhan yang terdapat pada amnion. Adanya dasar imunohistologi terhadap perkembangan jaringan granulasi yang berlimpah dan pembentukan pembuluh darah baru ketika amnion digunakan pada ulkus vena tungkai yang kronik. ${ }^{11}$ Pertumbuhan epitelisasi dari pinggir luka pada defek full thickness dan angka reepitelisasi dari partial thickness pada luka bakar tampak meningkat dengan menggunakan membran amnion. ${ }^{13,22}$

Penyembuhan reaksi kulit pada penelitian ini dinilai secara klinis menggunakan Skala RISRAS. Kontrol pasien yang dilakukan 2 kali dalam satu minggu sehingga tidak bisa diketahui pada hari ke berapa reepitelisasi mulai terjadi. Perlunya observasi terhadap pasien setiap hari untuk mengetahui kapan timbulnya reepitelisasi. 


\section{SIMPULAN}

Amnion liofilisasi menurunkan Skala RISRAS lebih cepat dibandingkan dengan salep gentamisin. Terdapat perbedaan efektifitas yang bermakna secara statistik antara amnion liofilisasi dengan salep gentamisin terhadap penyembuhan reaksi

\section{DAFTAR RUJUKAN}

1. Baskar R, Lee KA, Yeo R, Yeoh KW. Cancer and radiation therapy. current advances and future direction. Int J Med Sci 2012; 9(3): 193-9.

2. Salvo N, Barnes E, Dranen JV, Stacey E, Mitera G, Breen D, et al. Prophylaxis and management of acute radiation-induced skin reaction: a systematic review of the literature. Rad Oncol Current Oncol. 2010; 17(4):94 -112.

3. Chan RJ, Webster J, Chung B, Marquart L, Ahmed M, Garantziotis S. Prevention and treatment of acute radiation-induced skin reaction: a systematic review and metaanalysis of randomized controlled trials. BMC Cancer 2014:1-19.

4. Wells $M$, Macbride S. Suportive care in radiotherapy - radiation skin reaction. Elsevier 2003:135-59.

5. Khanna NR, Kumar DP, Laskar SG, Laskar S, 2013. Radiation dermatitis: an overview. Indian J Burns 2013; (21):24- 31.

6. McQuestion M. Evidence-based skin care management in radiation therapy. Semin Oncol Nurs 2011; 27(2):e1-17.

7. Paterson DB, Poonam $P$, Bennet NC, Peszynski RI, Beekhuizen MJ, Jasperse ML, et al. Randomized Intra-patient controlled trial of mepilex lite dressing versus aqueous cream in managing radiation-induced skin reactions post - mastectomy. J Cancer Sci Ther 2012; 4(11):347-56.

8. Diggelmann KV, Zytkovicz AE, Tuaine JN, Bennett NC, Kelly LE, Herst PM. Mepilex Lite dressing for the management of radiation-

p-ISSN: 0126-2092; e-ISSN: 2442-5230 kulit berdasarkan penilaian klinis Skala RISRAS pada penilaian minggu pertama. Amnion liofilisasi perlu dipertimbangkan sebagai salah satu modalitas terapi reaksi kulit akibat radioterapi di RSUP Dr. M. Djamil Padang

induced erythema: a systematic inpatient controlled clinical trial. British J Radiol 2010; 83:971-8.

9. Chan R, Webster J, Batistuta D, Chung B, Brooks L. Intervention for preventing and managing radiation-induced skin reaction in cancer patients (Protocol). Cohrane Collaborat 2010:1-11.

10. Allen LV. Compounding for wound care. current and practical compounding information for the pharmacist. Secundum Artem; 12(1).

11. Peter RU, 2015. Diagnosis and treatment of cutaneus radiation injuries. Panizzon RG, Seegen-schmiedt $\mathrm{MH}$, eds. Radiation treatment and radiation reaction in dermatology. $2^{\text {nd }}$ ed. Springer 2015:173-88.

12. Gajiwala AL and Sharma V. Use of irradiated amnion as a biological dressing in the treatment of radiation induced ulcer. Cell Tissue Bank 2003; 4:147-50.

13. Manjas M, Tarusaraya P, Hilmy N. The Use of Irradiated Amnion Grafts in Wound Healing. Dalam ( Nather A, Yusof N, Hilmy $\mathrm{N}$, ed ) Radiation in tissue banking. World Scientific Publishing CO 2007:329-42.

14. Zbuchea A. Up tu date use of amnion in surgery. Med Sci 2014; 7(56):87-92.

15. Manjas M, Henky J, Agus S. Penggunaan krim amnion pada penyembuhan luka sayatan tikus wistar. MKI 2010; 60(6):26872. 
16. Ganatra MA. Amniotic membran in surgery. Reviev Articles. J Pak Med Assoc 2003; 53(1):29-32.

17. Gunawan SG. Farmakologi dan terapi. Ed 5. Jakarta. Balai penerbit FKUI 2009:705-17.

18. Nasir A, Muhith A, Ideputri ME. Buku Ajar Metodologi Penelitian Kesehatan. Yogyakarta. Nusa Medika 2011.

19. Sastroasmoro S, Ismael S. Dasar-dasar metodologi penelitian klinis. Ed 2. Jakarta. S agung Seto 2002.

20. Kamalia N, Suzina, Yusof N. Changes in biophysical properties of human amniotic membranes after different preservation methods and radiation sterilization. J Tesma Reg Res 2014; 3(1):64-70.

21. Visvanath L, Bindhu J, Krishnamurthy B, Suresh KP. Granulocyte colony stimulating factor (G-CSF) accelerate healing of radiation induced moist desquamation. Klin Oncol 2012; 25(3):199-205.

22. Deocaris CC, Jacinto SD. Guzman ZM. Radiosensitivity of angiogenic and mitogenic factors in human amniotic membrane. Philippine J Sci 2003; 132(2):7783. 